\title{
Some Psycho-physiological Aspects of Ecstasy in Recent Research
}

\author{
By NORA AHLBERG
}

1

In this article it is my intention to present some psycho-physiological perspectives of recent date concerned with the phenomenon of ecstasy. As almost none of this research has as yet been assimilated by comparative religion and as it would not be possible for me to make a substantial contribution to the field in this connection, I will concentrate on illustrating some of the background for renewed speculation on the relationship between psyche and soma.

Traditional Western science has usually operated with a distinction between external and internal processes. Thus the nervous system of vertebrates has been thought of in terms of a central and an autonomous part. The latter is involved in such inner processes as digestion, heart rate or hormone balance. Because it is thought to be independent of our will power it is called autonomical.

Perhaps owing to this idea of the independence of our internal processes from our intentional consciousness, reports from other cultures such as those concerning the extraordinary achievements of holy men (e.g. their capacity to lie buried for days, or survive unclothed at very low temperatures) have tended to be ignored as fantastic rumours (which, to some extent, is certainly true) and myths. In a similar way the varieties of religious ecstatic states have often been countered with a shrug by psychiatrists. The recently renewed interest in consciousness within general psychology, together with what may be called marginal psychology and the drug revolt of youth culture have, however, provoked new speculation concerning human potential, speculation which in due time might also benefit comparative religion. This is particularly true with regard to research into so-called Altered States of Consciousness (which include ecstatic religious phenomena) (Ludwig 1968; Holm 1979, 13-62), although there is reason to warn against growing dilettantism in this field (Ahlberg 1980).

There are some known characteristics of this type of experience that are 
commony used as criteria, such as inffabilty, accompanyng analgesia loss of ego-idenity (that is the axperience of wholeness or oneness) in addition to the basic ecstatic wellbeing to which there are a few exceptions, sometines called he dak night of the soul. As $\mathbb{I}$ shall try to show, it is whth respect 10 these characteristics that recent research is able to contribute by ofering some psycho-physiological persperives.

Some of the explanatory models which have ganed renewed topicality in recent liveratue are actually rather old. Emst Arbman deals whin many of them in his conprohensive book Ecstasy or Religious Thane (1968). I would particularly like to emphasize his excellent treatment of hypnotical phenomena in relationship to, for example, the practice of yoga (Arbman $1968, I, 260.90$ ) and his treament of hysteria (Artman 1968, II, chap. IX) which emonstrates his thorough knowlodge of the field of psychiatry. At the present time, however, his book might in some respects seen rather old fashioned, based as it on the solid psychiatric theory of his time. Since then, anti psychatry has done away with many previous altitudes towards menul ilness and related religious phenomena. It is, however, only to be regretted that the book has not gained the reputation it so undeniably deserves within the field of the psychology of religion.

\section{2}

Aroman's (1968) interest in hallucinogenic drugs sems less marked, and perhaps rightly so, as the classic debate on authentic versus non-authentic or false mysticism, crystallized by Adous $\mathbb{H}$ uxley (1954) and R. C. Zaehner (1957; 1972), has become unduly emphasized through the interest of the "llower-power generation" in drug-induced Altered States of Consciousness and their clams of mysticism (Ahberg 1981, 232-43).

1 shall mot consider this question here but merely pomi out thet the discovery of endogenic opiates in the human brain has given this debate a ratier new direction. In the light of recent research it seems that not only the non-authentic but also the authentic mystical experiences might be conincted with drugs; thus much of the former debate has become supertuous. In any case, from the perspective of comparative religion the primary concern is wh cultural tradition and interpretation, athough the hallucinogenic drugs have opened up possibilities for a more experimental design as a complementary development in this area.

It was in 1973 athe John Hopkins School of Medicine in Batimore that a tean of researchers led by Dr. S. H. Snyder discovered that the human brain contained special ophate receptors (Pen \& Snyder 1973), and soon afterwards another tean succeded in isolating as syten of endorphines 
and one of encephalines located in parts of the brain thought to be connected mainly with emotions. It could now be asked whether these substances might be a key to the understanding of the typical euphoric and analgetic effects of spontaneous, non-drug induced Altered States of Consciousness.

Opiates are commonly held to be dangerous narcotics with mindaltering effects and it has now been shown that all of us are literally speaking addicted to ourselves. Expectations of having found the ideal analgetic substance were thus thwarted as it was discovered that these natural opiates have the same side effects as our ordinary opiate-derivative, the analgetic morphine.

Why do we have them? It is not yet known, but what is known is that like morphines they regulate the experience of pain. Thus we do know that patients with chronically severe pains exhibit a lower level of endorphines, that the concentration in all of us varies around the clock, and that these substances may also be involved in the explanation of the effect of acupuncture. An supply of morphias inhibits the production of endogenous opiates by invading the above-mentioned opiate receptors in our brain (so that no need for further internal production is triggered). This could be an explanation for the symptoms of abstinence connected with extended misuse of these types of drugs until the internal production through the feedback system again starts functioning. Furthermore, acupuncture has been used with some success in the treatment of drug addicts perhaps by stimulating the production of endogenous opiates. Besides, researchers now believe that the endogenous opiates may be active in connection with the so-called placeboeffect (that is, the effect of sugar-pills) which has previously been entirely attributed to psychic mechanisms (Mardsen 1979; Snyder 1977).

What does all this indicate? Human beings probably have a separate internal autonomic control system for pain which is activated in extraordinary circumstances as for example extreme stress (which could explain the often reported feeling of peace in the face of death). It is fascinating to speculate about a possible human capability for deciding the level of pain for oneself, for instance by means of yogic exercises. Could this be what so many a holy man has been reported to have done while enduring extreme heat, cold or other torture? We here face a correlate in the natural sciences to what common sense has known for a long time, that is the knowledge of cure by faith or the belief that with faith it is possible to move mountains at least in the inner landscape.

Moreover, it is also known that these natural opiates cooperate with a transmitter substance in the nervous system of our brain called serotonine which in its chemical structure resembles LSD. LSD has been regarded as a 
key towards understanding Altered States of Consciousness in the laboratory, with special reference to the experience of ego-loss (Harkness 1973, 161-64; Axelrod 1974). It has also been found that auditory hallucinations, which are so pronounced in schizophrenia but also found in religious experiences, correspond to an increased level of endogenous opiates and can be neutralized with the opiate antagonist naloxone (Mardsen 1979; Snyder 1977).

\section{3}

Among our many new potential methods for better understanding ecstatic phenomena by means of experimental methods, biofeedback has been the most sensational one. I have speculated on human ability to control the production of endogenous opiates. And it is above all the research in biofeedback that has forced many scientists to reconsider their view of the autonomic nervous system as a system completely independent of human will and control.

Typically, it was a rat experiment that was necessary to shake the convictions of many a sceptical researcher. This was first and foremost the achievement of Neal Miller and Leo DiCara at the Rockefeller University, their results indicating that a certain amount of learning by operant conditioning within the autonomic system could take place apparently without the involvement of will-controlled skeletal muscles (Miller 1969; DiCara 1970).

Despite a total paralysis due to curare the experimental rats showed themselves able to change the blood-flow in one ear as opposed to the other, being rewarded by electrical stimulation of the so-called pleasure centre of their brains. Unfortunately later attempts at replication of this brilliant series of experiments have not succeeded, a fact which has no satisfactory explanation. Later however, this type of experiment was continued and extended at Harvard by measuring different physiological processes such as blood-pressure or heart rate in students who had beer instructed in biofeedback (Shapiro, Tursky \& Schwarts 1970).

Biofeedback rests on the simple idea of letting a measuring apparatus register internal physiological changes which people normally, or because of some disease, do not seem sensitive enough to recognize. The intention is to examine the relationship between the physiological outcome on the measuring apparatus and consciousness in order to improve conscious control (Blanchard \& Epstein 1978; Sagberg 1977). Fig 1. Although the majority of these studies, in addition to their theoretical implications, have been adapted to therapeutic purposes (biofeedback training has been used 


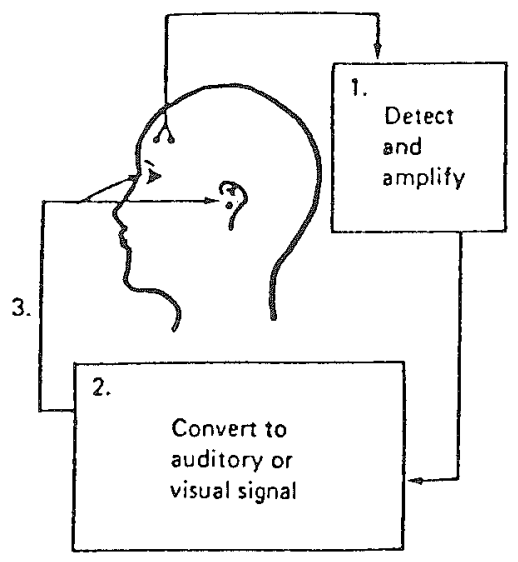

Fig. 1. 1, Detection and amplification of bioelectric potentials; 2, Convert bioelectric signals to easy-to-process information; 3 . Feed this information back to the patient; 4 , With immediate feedback, patient learns voluntary control response. (Blanchard 1978, 3.)

in the treatment of different psychosomatic illnesses such as hypertension) they have also initiated a more or less sensational so-called "alpha-cult" (Ahlberg 1980).

This alpha cult is connected with biofeedback research into the possibilities of voluntarily influencing brain activity as measured through EEG (that is, measuring electrical brainwaves). There has been some speculation that different EEG patterns would correlate with different forms of experience, thus alpha with ecstatic or meditative consciousness. Some counterculturally oriented persons have through biofeedback believed themselves to have found a short cut to nirvana or "nerve-ana". Although this "electronic yoga" practice has gained the largest number of adherents among the public searching for happiness it is probably the most complex form of biofeedback utilization concerning which there is much debate among researchers (Blanchard 1978, 128-29).

These "nerveanic" expectations are again connected with the equally recent experimental research in meditation, a theme which would need a separate article and thus cannot be dealt with here. It must suffice to state that a majority of these experiments concern recordings of physiological changes due to meditation (Lægevidenskabelig og psykologisk forskning 1978). Like the related research in biofeedback these experiments shake our conviction that the autonomy of inner processes excludes all possibilities of influencing the system, and thus to a certain extent demystify those strange phenomena reported by the study of religion. 
Most studies point in the direction of a gradual lowering of metabolism as a significant characteristic of the practice of meditation. It is Transcendental Meditation in particular that has been the object of research but some studies even try to explain the course of events during so-called coffin funerals which are reported to have taken place among oriental yogies (Anand et. al. 1961). One could probably state that whereas the method of biofeedback strengthens the internal signals so that they may be recognized, the practice of meditation often to the contrary lessens external distractions so that normally unconscious or autonomic internal processes can be brought into consciousness and thus controlled.

Most of the increasing interest in Altered States of Concsiousness could probably be integrated into the research and the more or less wild speculations produced in connection with study of the cerebral hemispheres. The human brain in fact actually consists of two bilaterally symmetrical brains. And one may naturally therefore ask whether man, accordingly, is equipped with two forms of consciousness and is thus a sort of Dr. Jekyll and Mr. Hyde.

It has been maintained that the father of experimental psychology Gustav Fechner (1801-87) was already concerned with this problem in that he speculated about the possibility of splitting our consciousness by cutting the corpus callossum or brain bridge, which constitutes the only connection between the two hemispheres (Blakemore 1977, 155). But it was not until the 1960s that a daring surgeon in California decided to cut the corpus callossum in patients afflicted by grave epilepsy which threatened to spread from one to the other hemisphere.

Strangely enough the results of this drastic operation turned out to have only minor negative effects in the everyday life of these patients and on the positive side the operation meant relief for their epileptical seizures. After closer examination, however, bizarre symptoms indicating that the hemispheres functioned independently of each other were discovered. Roger Sperry (who was later awarded the Nobel Prize for his discoveries in 1981) reported that the incision had left these patients with two separate spheres of consciousness (Sperry 1964; 1968). What was experienced by the left hemisphere seemed totally outside the consciousness of the right hemisphere. Later studies with normal experimental subjects (with an intact corpus callossum) or mental patients under electrical shock treatment in the Soviet Union also point in the same direction (Filbey \& Gazzaniga 1969; Deglin 1976). 


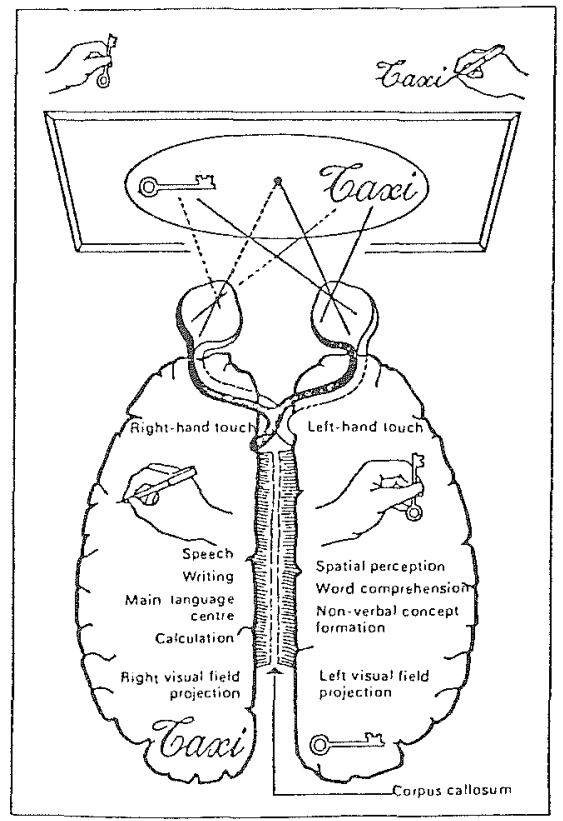

\section{LEFT HAND, RIGHT HAND}

Drawings below Illustrate the different capacities of the brain's two hemispheres. They were done by a patient whose left hemisphere had been separated from his right. He was asked to copy the cross and cube (centre) first with his left hand, then with his right hand. Although the petient was actually right-handed, he did a far better job petient was actually right-handed, he did a tar better job
with his left hand (controlled by the bran's right hemisphere. which excels at space perception) than with his right hand (governed by the spotially inept left hemisphere).

Fig. 2. Reprinted from the Unesco Courier Jan. 1976.

But the left consciousness is not totally identical with the right one. The most important difference is the fact that it is the left hemisphere which controls speech. Because the hemispheres control the opposite side of the body the right hand is for example controlled by the left hemisphere and vice versa. If a so called split-brain patient with his eyes shut receives an object in his left hand he will be unable to identify even the most common object verbally. But given the task of pointing out the object in question from among other objects lying in front of him he will be able to do this with his left hand. His right hand/left brain, however, seems to be totally unconscious of what happens to the other side (Gazzaniga 1967; Deglin 1976). Fig. 2.

The right hemisphere is associated with non-verbal visio-spatial skills (such as visual images or music) in contrast the the verbal, left side. This point is also supported by findings in connection with damage to the respective hemispheres (Bogen 1964-72; Deglin 1976, 13-14). The discovery of hemispheric specialization has since resulted in a growing movement of protest aiming at the liberation of the right hemisphere in what is felt to be our verbal-logically and technologic-scientifically dominated western 
society, where-according to these enthusiasts-there exists a sort of dictatorship by the left hemisphere.

Perhaps the best known exponent of such ideas is the American psychologist Robert Ornstein $(1969 ; 1972 ; 1973)$ whose writings may, from the point of view of comparative religion, often seem unduly simplified. Like others of the same opinion he connects the specialization of the hemispheres with a fundamental dualism between reason and emotion or consciousness and unconsciousness. He reports, for example, an experiment where the right non-verbal or unconscious hemisphere, in the middle of an otherwise boring laboratory experiment, is confronted with a photograph of a nude woman. Verbally, the subject in question denies that he has seen anything special which, due to the design of the experiment, is the case with his verbal, left hemisphere. But at the same time he blushes and giggles "without reason", as Ornstein $(1972,60)$ comments, with his conscious ego.

Unconsciousness would thus be a question of the degree of communication between the hemispheres through the brain bridge. Analogically to this, creativity would be a capacity to translate unconscious experiences in the right hemisphere to left hemispheric verbal categories or an integration by means of the corpus callossum. With creativity is also associated religious ecstatic or meditative states, while schizophrenia is explained as a sort of disintegration of the inter-hemispheric coordination in this simplified organically oriented thinking (Fisher 1975; Deglin 1976; 14-16, 31-32).

But anthropological circles have also, somewhat unexpectedly, shown interest in this question, an interest which can be traced back to an article by Robert Hertz (one of Durkheims pupils) "La Prééminence de la main droite: étude sur la polarite religieuse" from 1909, where he states that the explanation of the almost universal dominance of the right hand over the left is, in the last resort, to be found in the human organism, that is, we are right handed because we are left-brained (some of the approximately $5 \%$ of left-handed persons constitute exceptions).

At the same time he emphasizes the cultural constructions based on this fact, and traces the dichotomy back to the primitive concept of cosmos as divided into two spheres; a masculine one, which is strong, good and holy and a feminine one, which is weak, evil and profane. This cosmic division is said to be reflected in primitive man's own microcosmos so that the positive side is identified with the naturally more developed right hand (which is dominated by the left brain).

The article is reprinted in the book Left and Right edited by Rodney Needham (1973) and serves as a point of departure for a number of interesting articles concerning right-left symbolism in different cultures. 
They deal with such concepts as yin-yang in China, right and left in Greek philosophy or against the background of Arabic evidence, but in particular there are examples from African cultures. Probably the most notable of these is Evans Pritchards "Nuer Spear Symbolism" (1973), where he interpretes the spear as an extension of the dominating right hand in Nuer culture, and gives the credit due to Hertz's pioneering work. At the present time, one can only state that there is a tendency towards idealizing the right hemisphere and attributing to it introvertive capacities and experiences connected with so-called human peak experiences such as, for instance, creativity or ecstasy (Maslow 1959).

With considerable foresight, Heinz concluded his article as follows:

If the constraints of a mystical ideal have for centuries been able to make man into a unilateral being, physiologically mutilated, a liberated and enlightened society will strive to develop the energies dormant in our right cerebral hemisphere, and to assure by appropriate training a more harmonious development of the organism (Hertz 1973, 22).

And forty-four years later Ornstein $(1972,66)$ writes that it is precisely the complementarity of the two hemispheres which is his central interest as it finds expression simultaneously on many levels. One side, according to him, is analytical, the other holistic, one linear and rational, the other arational and intuitive.

The idea of a split in our consciousness or its complementarity is not unknown as such either to psychologists/psychiatrists or to students of comparative religion interested in Altered States of Consciousness. What is more interesting is that this duality seems to a certain extent to have an anatomic-physiological as well as a psychological and cultural dimension, and that the first mentioned fact increases our possibilities of research in ecstatic phenomena with methods borrowed from the natural sciences.

\section{5}

In the future, discoveries in such traditionally remote fields as psychophysiology, will probably to a greater extent complement the data of comparative religion and contribute to a growing understanding of the internal processes which are so important to religion. Not least, some of the traditionally more inaccessible phenomena of the psychology of religion such as religious ecstasy, may be introduced to the laboratory under strictly controlled conditions. This again will contribute to the prestige of the psychology of religion, which has been somewhat neglected within comparative religion since the beginning of this century. 
I should like to conclude with the following hypotheses:

- that the ecstatic consciousness is, if not produced by, at least dependent on so called natural opiates in the human brain

- that this explains its analgetic effects

- that the basis for the unifying mechanisms of mystical ecstatic experience is a transfer of mastery from the left to the right hemisphere. Some $\mathrm{EEG}$ recordings seem to imply that this is the case at least as far as dreams, hallucinations or meditation are concerned (Goldstein \& Stoltzfus, $1972 \mathrm{a}, 1972 \mathrm{~b}, 1973$ )

- that the ineffability of Altered States of Consciousness is related to the inability of the right hemisphere to express itself verbally as shown in connection with Sperry's splitbrain patients.

\section{References}

Ahlberg, N. 1980. Biofeedback som marginalpsykologiskt fenomen (unpubl. manus.).

- 1981. Vastakulttuuri todellisuutta haastattelemassa. Äidinkielen Opettajain Vuosikirja.

Anand, B. et al. 1961. Studies on Shri Ramananda during his stay in an airtight box. Indian journal of medical research 49, 82-89.

Arbman, E. 1968. Ecstasy or religious trance 1-3. Uppsala.

Axelrod, J. 1974. Neurotransmitters. Scientific American June 58-71.

Blakemore, C. 1977. Mechanics of the mind. Cambridge.

Blanchard, E.-Epstein, L. 1978. A biofeedback primer. Massachusetts.

Bogen, J. 1964. The other side of the brain 1. Bulletin of the Los Angeles neurological society $34,73-105$.

- 1969. The other side of the brain 2-3. Bulletin of the Los Angeles neurological society $34,135-62 \& 191-220$.

- 1972. The other side of the brain 4. Bulletin of the Los Angeles neurological society $37,49-61$.

Deglin, V. 1976. Our split brain 1-4. The Unesco Courier Jan, 4-16 \& 31-32.

DiCara, L. 1970. Learning in the autonomic nervous system. Scientific American Jan, $30-39$.

Filbey, R.-Gazzaniga, M. 1969. Splitting the normal brain with reaction time. Psychonomic science 17, 335-36.

Fischer, R. 1975. Cartography of inner space. Hallucinations. Behavior, Experience \& Theory, ed. by I. Stegel-L. West. New York. 213-20.

Gazzaniga, M. 1967. The split brain in man. Scientific American. Aug 217, 24-29.

Goldstein, L.-Stoltzfus, N. 1972a. Drug-induced changes of interhemispheric EEG amplitude relationships in man. 5th international congress of pharmacology. July. Abstracts 505. San Francisco.

- 1972 b. Changes in interhemispheric amplitude relationships in the EEG during sleep. Physiology and behavior 8, 811-16. 
- 1973. Psychoactive drug-induced changes of interhemispheric EEG amplitude relationships. Agents and actions 3, 124-32.

Harkness, G. 1973. Mysticism. London.

Hertz, R. 1909. La prééminence de la main droite; étude sur la polarité religieuse. Revue philosophique 68, 553-80.

Holm, N. G. 1979. Mystik och intensiva upplevelser. Åbo. (Publications of the Research institute of the Abo Akademi Foundation 51.)

Huxley, A. 1954. The doors of perception. New York.

Lagevidenskabelig og psykologisk forskning på yoga \& meditation. 1978. Kфbenhavn.

Ludwig, A. 1968. Altered states of consciousness. Trance and possession states ed. by I. Prince. Montreal.

Mardsen, C. 1979. The emotion of pain and its chemistry. Symposium on Brain and Mind. CIBA Foundation (new series) 69, 304-14.

Maslow, A. 1959. Religious values and peak experiences. New York.

Miller, N. 1969. Learning of visceral and glandular responses. Science 163, 434-45.

Ornstein, R. 1969. On the experience of time. Harmondsworth.

- 1972. The psychology of consciousness. San Fransisco.

- 1973. The nature of human consciousness. San Fransisco.

Pert, C.-Snyder, S. 1973. Opiate Receptor: demonstration in nervous tissue. Science 197, 1011-14.

Pritchard, E. 1973. Nuer spear symbolism. Right and left, ed. by R. Needham. Chicago.

Sagberg, F. 1977. Biofeedback-psykologisk adferdsterapi. Impuls 31, 28-37.

Shapiro, D.-Tursky, B.-Schwartz, G. 1970. Differentation of heart rate and systolic blood pressure in man by operant conditioning. Psychosomatic medicine 32, 417-23.

Snyder, S. 1977. Opiate receptors and internal opiates. Scientific American March, $44-56$.

Sperry, R. 1964. The great cerebral commissure. Scientific American Jan, 142-52.

- 1968. Mental unity following surgical disconnection of the cerebral hemispheres. The Harvey lecture series 62, 293-323.

Zaehner, R. 1957. Mysticism sacred and profane. Oxford.

- 1972. Drugs, mysticism and make-believe. London. 